\title{
Diversity of Soil Insect in Kerandangan Ecotourism Nature Park Area West Lombok Island
}

\author{
Mery Rosinta ${ }^{1}$ I Putu Artayasa ${ }^{1 *}$, Mohammad Liwa Ilhamdi ${ }^{1}$ \\ Program Studi Pendidikan Biologi, Fakultas Keguruan dan Ilmu Pendidikan, Universitas Mataram, \\ Indonesia
}

\author{
Article History \\ Received : August $16^{\text {th }}, 2021$ \\ Revised : August $30^{\text {th }}, 2021$ \\ Accepted : September $15^{\text {th }}, 2021$ \\ Published : September $25^{\text {th }}, 2021$ \\ *Corresponding Author: \\ I Putu Artayasa, \\ Program Studi Pendidikan \\ Biologi, Fakultas Keguruan dan \\ Ilmu Pendidikan, Universitas \\ Mataram, Indonesia \\ E-mail: artayasa75@unram.ac.id
}

\begin{abstract}
The role of soil insects is very important as environmental indicator organisms, balancing ecosystems, and helping the process of soil decomposition. This study aims to determine the diversity of soil insects in the Kerandangan Ecotourism Nature Park (ENP) West Lombok. The diversity of flora and fauna that it has makes ENP Kerandangan suitable as an ecotourism area that offers interesting tourist objects as well as educational facilities. Sampling was carried out using the pitfall trap method. Samples were taken at three stations. The first station is in the southern forest of Kerandangan Nature Tourism Park, the second station is in the middle and the third station is in the north forest of Kerandangan Nature Tourism Park. Data were analyzed using the Shannon-Wiener diversity index. The results showed that there were 12 types of insects belonging to 7 orders and 11 families, totaling 595 individuals. Insect species were dominated by insects from the family Carabidae, namely the genus Harpalus as many as 178 individuals. In general, the index value of soil insect species diversity in the Kerandangan TWA forest area is 1.768. The highest species diversity index value was at station 2 , namely $H^{\prime}=1.772$. while the lowest is at station 3 , namely $H^{\prime}=1.488$. In conclusion, the diversity of soil insects in the Kerandangan Nature Tourism Park, West Lombok, varied at each station and in general the level of soil insect diversity in the Kerandangan Nature Tourism Park was categorized as moderate.
\end{abstract}

Keywords: Insect Diversity, Soil Insect, Kerandangan.

\section{Pendahuluan}

Hutan Kerandangan adalah kawasan konservasi yang berada di Desa Senggigi, wilayah Kecamatan Batu Layar, Kabupaten Lombok Barat, Provinsi Nusa Tenggara Barat (NTB). Kawasan konservasi tersebut berada di bawah pengelolaan Balai Konservasi Sumberdaya Alam (BKSDA) NTB. Berdasarkan Surat Keputusan (SK) Menteri Kehutanan No. 494/Kpts-II/92, tanggal 1 Juni 1992, Hutan Kerandangan berstatus sebagai Taman Wisata Alam (TWA). Hutan tersebut memiliki luas 396,10 ha. Secara astronomis, letak hutan konservasi tersebut adalah pada $8^{\circ} 20^{\prime} 13^{\prime \prime}$ $8^{\circ} 20^{\prime} 15^{\prime}$ ' LS dan $116^{\circ} 04^{\prime} 00^{\prime}$ ' - 116 $04^{\circ} 03^{\prime}$ ' BT (BKSDA, 2018).
Hutan Kerandangan memiliki tipe vegetasi berupa hutan musim dataran rendah. Berdasarkan klasifikasi Schmidt-Ferguson, tipe iklim yang dimiliki Hutan Kerandangan adalah tipe iklim D. Tipe iklum ini sangat dipengaruhi oleh angin muson. Curah hujan di kawasan tersebut adalah berkisar antara $1500 \mathrm{~s} / \mathrm{d} 2000 \mathrm{~mm}$ per tahun. Pada umumnya di hutan tersebut hujan turun dari bulan November sampai bulan Mei. Temperatur minimum dan maksimum di sekitar daerah tersebut adalah $20,8^{\circ} \mathrm{C}$ dan $37^{\circ} \mathrm{C}$. Tipe vegetasi pada TWA Kerandangan adalah vegetasi campuran berupa pohon-pohon tinggi yang bercampur dengan tumbuhan perdu dan semak yang membentuk lapisan-lapisan tajuk tertutup (BKSDA, 2018). Beberapa macam tumbuhan tinggi yang terdapat di 
TWA Kerandangan adalah: Kelicung (Dyospiros malabarica), kemudian Terep (Arthocarpus elastica), Sentul (Aglaia sp.), Beringin (Ficus benjamina), tumbuhan Goak (Ficus sp.), Klokos Udang (Dracontomellon mangiferum) dan Jukut (Eugenia sp.) (Suana et al, 2016).

Di kawasan TWA Kerandangan terdapat objek wisata yang sangat menarik sehingga menjadi kawasan favorit bagi wisatawan lokal dan turis. Objek wisata tersebut berupa dua air terjun yang menjadi Objek Daya Tarik Wisata (ODTW) utama yakni, Air terjun Putri Kembar dan Air terjun Goa Walet. Keberadaan kedua air terjun tersebut bersumber dari adanya mata air yaitu, mata air Eat Beraik. Beberapa kegiatan wisata yang dapat dilakukan misalnya Camping, Jungle Tracking, Jelajah Sungai, Pengamatan Satwa, serta Pendidikan Lingkungan. Keanekaragaman flora dan fauna yang dimilikinya menjadikan TWA Kerandangan cocok sebagai kawasan ekowisata yang menyajikan berbagai ODTW sekaligus sebagai wisata edukasi, sehingga dapat meningkatkan jumlah wisatawan yang berkunjung. Adanya fenomena ekologi berupa simbiosis pada tumbuhan merambat (Liana) seperti tumbuhan kentang gantung dengan pohon terep (Arthocarpus elastica) menyebabkan TWA tersebut semakin menarik sebagai daerah wisata alam. Selain sebagai daerah wisata alam yang menyajikan aktivitas wisata yang memberikan pengalaman menjelajahi alam dengan panorama yang menarik, TWA Kerandangan juga menyediakan daerah ekowisata birdwatching. Ekowisata yang berorientasi pada lingkungan ini ditujukan untuk dapat menjembatani antara kepentingan perlindungan sumberdaya alam/lingkungan dan kepentingan industri kepariwisataan (BKSDA, 2018). Di TWA Kerandangan terdapat 56 spesies burung yang termasuk kedalam 31 famili (Suana et al., 2016).

Keberadaan tumbuhan di TWA Kerandangan tak dapat dilepaskan oleh peran hewan tanah dalam penyediaan bahan organik tanah. Kelompok hewan tanah sangat beragam, salah satunya berasal dari kelompok Arthropoda kelas insekta. Umumnya hewan tanah diketahui berperan sebagai perombak bahan organik sehingga berkontribusi dalam proses daur ulang materi tanah. Peran signifikan hewan tanah tersebut tidak dapat langsung dirasakan oleh manusia, melainkan ketika selesai melewati serangkaian proses yang melibatkan biota tersebut. Oleh karena itu, tanpa adanya peran fauna tanah maka degradasi tumpukan bahan organik di lingkungan akan berjalan lambat. Serangga tanah sebagai salah satu fauna tanah berpotensi dalam perombakan bahan organik tanah sehingga menjadikannya penyeimbang lingkungan (Rachmasari et al., 2016).

Serangga telah hidup di bumi sekitar 350 juta tahun maka tidak dapat dipungkiri proses evolusi serangga telah banyak terjadi. Evolusi tersebut menyebakan serangga dapat menyesuaikan kehidupannya hampir pada setiap tipe habitat. Fenomena ini menjadikan kehadiran atau ketidakhadiran serangga sebagai bioindikator lingkungan yang signifikan (Subekti, 2012). Serangga tanah memiliki peran signifikan dalam ekosistem, yakni menyebabkan pelapukan bahan organik menjadi bahan sederhana yang berguna sebagai unsur hara tanaman, dengan kata lain keberadaannya berpengaruh positif terhadap sifat kimia dan fisika tanah. Serangga tanah yang merombak bahan organik kompleks di dalam tanah menjadi bahan yang lebih sederhana, kemudian melepaskan hasil rombakannya tersebut ke dalam tanah dalam bentuk unsur hara bagi tumbuhtumbuhan hijau (Basna et al., 2017). Salah satu serangga tanah yang berkontribusi signifikan terhadap proses perombakan bahan organik tanah yaitu semut. Hewan tersebut berfungsi sebagai detritivor yaitu menghancurkan serasah atau materi organik dengan cara memakannya. Serangga tanah lain yang berperan sebagai perombak bahan organik tanah adalah rayap (Isoptera), kemudian lebah penggali tanah (Hymnoptera), kumbang (Coleoptera), lalat (Diptera), dan berbagai Aphid (Homoptera) (Borror et al., 1996).

Keberadaan serangga tanah dapat menjadi indikator keseimbangan ekosistem yang artinya bila dalam suatu ekosistem mempunyai keanekaragaman serangga yang tinggi maka mengindikasikan lingkungan di ekosistem tersebut seimbang atau stabil. Adanya keanekaragaman serangga tanah yang tinggi berdampak terhadap terjadinya proses pembentukan jaring-jaring makanan yang berjalan normal. Begitu sebaliknya apabila di suatu ekosistem terdapat keanekaragaman serangga yang rendah maka artinya lingkungan ekosistem tersebut memiliki ketidakseimbangan atau labil, karena adanya perubahan-perubahan pada ekosistem akan 
menyebabkan terjadinya keseimbangan baru. Hal ini sesuai dengan pendapat Suhaeriyanto (2008) bahwa keseimbangan ekosistem itu diatur oleh berbagai faktor yang sangat rumit tergantung bagaimana keberadaan komponen-komponen ekosistem tersebut.

Serangga berperan penting sebagai bioindikator yaitu untuk mengetahui kondisi kesehatan suatu lingkungan ekosistem (Subekti, 2012). Kehadiran suatu jenis serangga pada suatu ekosistem dapat berperan sebagai indikator pencemaran, salah satunya ialah capung (Ilhamdi, 2012 dan 2018). Capung dapat dijadikan sebagai bioindikator air bersih yakni digunakan untuk memonitoring kualitas air di suatu lingkungan, hal ini disebabkan karena kebiasaan capung melakukan aktivitas perkembangbiakan pada lingkungan perairan yang relatif bersih. Berdasarkan pola perilaku perkembangbiakan capung tersebut apabila terjadi perubahan jumlah populasi capung secara signifikan maka hal tersebut dapat merupakan sinyal untuk mengambil langkah awal untuk menyusun program perlindugan terhadap lingkungan yang terindikasi mengalami pencemaran (Ilhamdi et al., 2019).

Serangga akuatik seperti Ephemeroptera juga dapat digunakan sebagai bioindikator pencemaran air pada suatu daerah. Apabila serangga air dari famili Ephemeroptera tidak ditemukan menandakan suatu lingkungan telah tercemar. Kumbang dari famili Carbidae dapat digunakan sebagai indikator manajemen lahan pertanian (Subekti, 2012). Semut, rayap, dan kupukupu juga dapat berperan sebagai bioindikator lingkungan karena memberikan respons yang khas terhadap tingkat kerusakan hutan. Potensi serangga-serangga tersebut sebagai bioindikator dapat dimanfaatkan untuk mendeteksi adanya perubahan lingkungan akibat konversi hutan oleh manusia sehingga serangga tersebut sekaligus digunakan sebagai indikator kesehatan hutan (Maulana et al., 2016).

Tingkat keanekaragaman serangga tanah pada berbagai tempat dapat berbeda-beda karena menurut Borror (1996), kehadiran serangga tanah pada suatu ekosistem dibatasi oleh faktor-faktor geologi dan ekologi. Faktor pembatas lingkungan tersebut dapat berupa adanya perbedaan iklim, perbedaan musim, perbedaan ketinggian tempat, dan perbedaan nutrisi atau jenis makanan yang tersedia (Haneda et al., 2013). Bahkan keberadaan aliran sungai yang melintasi suatu kawasan hutan dapat menjadi pemicu perbedaan jumlah dan jenis serangga. Faktor-faktor lingkungan lainnya yang mempengaruhi kehadiran suatu spesies serangga pada suatu habitat yaitu kondisi suhu udara, tingkat kelembaban udara dan tanah, intensitas cahaya, tingkat curah hujan, macam vegetasi, ketersediaan makanan, seleksi habitat dan kemampuan serangga untuk menyebar (Maulana et al., 2016).

Karakteristik kondisi lingkungan yang berbeda juga menyebabkan kelimpahan serangga yang berbeda. Fluktuasi Suhu lingkungan akan dapat mempengaruhi pola aktivitas serangga, penyebaran geografis, penyebaran lokal, dan perkembangan serangga. Misalnya, kelembaban udara dan tanah dapat berpengaruh terhadap tingkat penguapan cairan tubuh serangga dan pemilihan habitat yang tepat. Faktor lingkungan berupa suhu dan kelembaban dapat terlihat pengaruhnya terhadap pola perubahan kelimpahan dan keanekaragaman serangga apabila pengambilan sampel dilakukan pada musim yang berbeda dan dengan waktu yang lama (Haneda et $a l .$, 2013). Hal ini didukung dengan hasil penelitian Ruslan dan Noor (2007) yang diacu dalam Haneda et al. (2013) bahwa kelimpahan anggota famili Formicidae dan Nitidulidae meningkat pada permukaan tanah dimusim kemarau, sedangkan famili Tonebrionidae mengalami peningkatan jumlahnya pada permukaan tanah di musim hujan. Hutan Kerandangan sebagai daerah taman wisata alam memiliki kondisi lingkungan yang sangat baik dengan biota asosiasinya yang melimpah seperti serangga. Berdasarkan hal tersebut, dalam perkuliahan Ekologi Hewan dan Zoologi Invertebrata, topik tentang taksonomi, morfologi, dan ekologi serangga menjadi objek utama dalam praktikum kedua mata kuliah tersebut. Dengan ditemukan tempat hidup alami dari hewan ini membantu pengembangan pembelajaran serangga secara langsung untuk mengamatinya yang tidak hanya dibahas dalam teks. Sejalan dengan hal tersebut maka penelitian tentang keanekaragaman serangga tanah penting dilakukan untuk memperkaya bahan pembelajaran IPA khususnya Biologi (Ilhamdi, 2012). Informasi yang terkumpul mengenai serangga tanah masih sedikit akibat penelitian yang masih jarang dilakukan terutama di Indonesia, di sisi lain serangga tanah mempunyai peranan yang cukup penting, oleh karena itu keberadaannya perlu diungkapkan dengan salah 
satu cara, yaitu melakukan inventarisasi (Patang, 2010).

Serangga tanah yang hidup di TWA Kerandangan merupakan kekayaan alam hayati yang memiliki nilai ekonomi, nilai ekologi, keindahan, serta dijadikan bahan penelitian dan bioindikator kualitas lingkungan sehingga menunjang ekowisata. Penelitian berfokus mengkaji keanekaragaman serangga tanah di TWA Kerandangan belum pernah dilakukan, sehingga belum ada informasi tentang serangga tanah baik dari segi taksonomi maupun dari segi ekologinya di kawasan tersebut. Oleh karena itu penelitian mengenai keanekaragaman serangga tanah di TWA Kerandangan Lombok Barat perlu dilakukan.

\section{Bahan dan Metode}

Penelitian ini dilaksanakan dengan mengacu metode eksplorasi (penelitian penjajakan), artinya pengamatan atau pengambilan sampel dilakukan langsung di lokasi pengamatan dengan menggunakan pitfall trap. Pengambilan sampel dengan menggunakan alat perangkap pitfall trap bertujuan untuk menangkap serangga yang berjalan di atas permukaan tanah. Alat ini terdiri dari sebuah wadah penampung yang berisi larutan detergen untuk mencegah serangga yang sudah terjebak melarikan diri dan formalin sebagai bahan untuk mengawetkan serangga yang tertangkap. Pengambilan sampel dilakukan dengan cara memasang perangkap jebak yaitu 20 buah dan 2 buah dijadikan sebagai sebagai cadangan.

Perangkap diisi dengan larutan detergen dan formalin 4\% secukupnya pada masing-masing gelas perangkap kemudian dipasang secara zig zag. Pemasangan mulut gelas perangkap sejajar dengan permukaan tanah sehingga serangga yang berjalan dipermukaan tanah diharapkan terjatuh ke dalam gelas perangkap. Pemasangan perangkap dilakukan dengan selang waktu 1 minggu. Sampel diambil dari tiga stasiun yaitu stasiun I disebelah selatan hutan TWA Kerandangan, stasiun II di daerah tengah dan stasiun III di sebelah utara hutan TWA Kerandangan. Pengambilan data dilakukan sebanyak tiga kali ulangan. Serangga yang terkumpul kemudian dilakukan pengidentifikasian di Laboratorium Biologi FKIP Universitas Mataram. Data hasil identifikasi dan penghitungan kemudian dianalisis menggunakan rumus indeks keanekaragaman Shannon Wiener yaitu :

$$
H^{\prime}=-\sum P i \ln P i \text { dimana } P i=n i / N
$$

Keterangan rumus :

$H^{\prime} \quad=$ Indeks keanekaragaman Shannon-Wiener

$P i \quad=$ Proporsi spesies ke $i$ di dalam sampel total

$n i \quad=$ Jumlah individu dari setiap jenis

$N \quad=$ Jumlah total individu dari seluruh jenis

Besarnya nilai $H^{\prime}$ dikelompokan menjadi tiga indikator sebagai berikut:

$$
\begin{aligned}
& H^{\prime}<1 \quad: \text { Keanekaragaman rendah } \\
& H^{\prime} 1-3 \quad: \text { Keanekaragaman sedang } \\
& H^{\prime}>3 \quad: \text { Keanekaragaman tinggi } \\
& \text { (Soegianto, 1994). }
\end{aligned}
$$

\section{Hasil dan Pembahasan}

Hasil penelitian mengenai keanekaragaman spesies serangga di kawasan hutan TWA Kerandangan menunjukkan bahwa terdapat 12 jenis serangga yang tergolong ke dalam 7 ordo dan 11 famili, yang seluruhnya berjumlah 595 individu. Ketujuh ordo tersebut meliputi, Coleoptera, Dermaptera, Homoptera, Hymenoptera, Orthoptera, Isoptera dan Spirobolida. Spesies serangga didominasi oleh serangga dari famili Carabidae yaitu genus Harpalus sebanyak 178 individu (Tabel 1). Genus ini banyak ditemukan di daun-daun, kayu-kayu dan permukaan tanah yang banyak serasah dan dekat air mengalir, terutama di stasiun 2 yakni dibagian tengah kawasan hutan. Pada lokasi ini terdapat banyak serasah dekat aliran sungai.

Indeks keanekaragaman (H') serangga tanah dihitung dengan menggunakan rumus Shannon-Wiener. Besarnya nilai $H^{\prime}$ tersebut menggambarkan tingkat keanekaragaman suatu organisme dalam suatu ekosistem. Nilai indeks keanekaragaman didasarkan atas jumlah spesies dan kelimpahan relatif jenis pada suatu komunitas (Price, 1997). 
Tabel 1. Jumlah Serangga Tanah di Taman Wisata Alam Kerandangan

\begin{tabular}{|c|c|c|c|c|c|c|c|c|c|c|}
\hline \multirow[b]{2}{*}{ No. } & \multirow[b]{2}{*}{ Nama Spesies } & \multicolumn{3}{|c|}{ Pengulangan 1} & \multicolumn{3}{|c|}{ Pengulangan 2} & \multicolumn{3}{|c|}{ Pengulangan 3} \\
\hline & & $\begin{array}{c}\text { Stasiun } \\
1 \\
\end{array}$ & $\begin{array}{l}\text { Stasiun } \\
2\end{array}$ & $\begin{array}{c}\text { Stasiun } \\
3 \\
\end{array}$ & $\begin{array}{c}\text { Stasiun } \\
1 \\
\end{array}$ & $\begin{array}{l}\text { Stasiun } \\
2\end{array}$ & $\begin{array}{c}\text { Stasiun } \\
3 \\
\end{array}$ & $\begin{array}{c}\text { Stasiun } \\
1 \\
\end{array}$ & $\begin{array}{l}\text { Stasiun } \\
2\end{array}$ & $\begin{array}{c}\text { Stasiun } \\
3\end{array}$ \\
\hline 1 & $\begin{array}{l}\text { Capnochroa } \\
\text { fuliginosa }\end{array}$ & 22 & 13 & 0 & 20 & 13 & 5 & 9 & 18 & 2 \\
\hline 2 & Calosoma sp. & 6 & 2 & 4 & 2 & 7 & 2 & 2 & 12 & 1 \\
\hline 3 & Harpalus sp. & 14 & 29 & 9 & 26 & 33 & 24 & 27 & 13 & 3 \\
\hline 4 & $\begin{array}{l}\text { Deltochilum } \\
\text { fuspocupreum }\end{array}$ & 0 & 0 & 0 & 10 & 18 & 2 & 3 & 1 & 0 \\
\hline 5 & $\begin{array}{l}\text { Euborellia } \\
\text { annulipes }\end{array}$ & 0 & 0 & 0 & 1 & 1 & 0 & 0 & 0 & 0 \\
\hline 6 & $\begin{array}{l}\text { Forficula } \\
\text { auricularia }\end{array}$ & 4 & 0 & 0 & 1 & 1 & 4 & 5 & 3 & 2 \\
\hline 7 & Pacarina sp. & 0 & 0 & 0 & 0 & 0 & 0 & 1 & 0 & 0 \\
\hline 8 & $\begin{array}{l}\text { Dolichoderus } \\
\text { thoracicus }\end{array}$ & 13 & 24 & 34 & 22 & 8 & 20 & 12 & 27 & 22 \\
\hline 9 & Gryllus integra & 0 & 2 & 3 & 0 & 2 & 0 & 0 & 0 & 1 \\
\hline 10 & Valanga nigriconis & 1 & 1 & 4 & 0 & 0 & 0 & 0 & 0 & 0 \\
\hline 11 & Captotermes sp. & 0 & 4 & 1 & 0 & 0 & 0 & 4 & 2 & 5 \\
\hline \multirow[t]{2}{*}{12} & $\begin{array}{l}\text { Trigoniulus } \\
\text { corallinus }\end{array}$ & 3 & 1 & 0 & 2 & 2 & 0 & 0 & 0 & 0 \\
\hline & Jumlah & 63 & 76 & 55 & 84 & 85 & 57 & 63 & 76 & 36 \\
\hline
\end{tabular}

Secara umum nilai indeks keanekaragaman spesies serangga tanah pada kawasan hutan TWA Kerandangan adalah 1,768 yang termasuk dalam kategori sedang. Nilai Indeks keanekaragaman serangga tanah pada tiga stasiun penelitian bervariasi dari sebesar 1,488 sampai 1,772. Nilai indeks keanekaragaman spesies tertinggi terdapat pada stasiun 2, sedangkan yang terendah terdapat pada stasiun 3. Adapun nilai indeks dominansi (D) spesies serangga tanah di kawasan hutan TWA Kerandangan secara umum adalah 0,002 dengan rentang nilai 0,004-0,007 yang termasuk kategori rendah (Tabel 2).

Tabel 2. Nilai indeks keanekaragaman (H') dan indeks dominansi (C) di Taman Wisata Alam Kerandangan

\begin{tabular}{ccc}
\hline Stasiun & $\begin{array}{c}\text { Indeks Keanekaragaman } \\
\left(\mathbf{H}^{\prime}\right)\end{array}$ & $\begin{array}{c}\text { Indeks Dominansi } \\
(\mathbf{C})\end{array}$ \\
\hline Stasiun 1 & 1.746 & 0.005 \\
Stasiun 2 & 1.772 & 0.004 \\
Stasiun 3 & 1.488 & 0.007 \\
\hline Seluruh stasiun & 1,768 & 0,002 \\
\hline
\end{tabular}

Keanekaragaman serangga dipengaruhi oleh faktor kualitas dan kuantitas makanan yang tersedia di lingkungannya, seperti, banyaknya tanaman inang yang cocok, umur tanaman inang, kerapatan tanaman inang dan komposisi tanaman tegakan.
Keanekaragaman serangga tanah yang sedang disebabkan oleh faktor abiotik yaitu curah hujan yang tinggi saat pengambilan data karena kegiatan penelitian dilakukan saat musim penghujan. Curah hujan yang terlalu tinggi memungkinkan efektifitas 
alat perangkap jebak yang dipasang menjadi kurang, karena banyak serangga tidak aktif saat hujan tinggi, serta botol perangkap jebak terisi banyak air sehingga memudahkan serangga yang telah masuk perangkap dapat keluar lagi.

Faktor fisik lingkungan berdasarkan hasil penelitian ini termasuk mendukung keberadaan serangga di TWA Kerandangan, dapat dilihat pada
Tabel 3. Suhu di daerah TWA Kerandangan berkisar $25-30^{\circ} \mathrm{C}$. Intensitas cahaya rata-rata menunjukkan $5 \mathrm{Cd}$. Nilai $\mathrm{pH}$ tanah di lahan tersebut sebesar 7, artinya kondisi tanah tidak asam dan tidak basa (netral). Musim hujan umumnya jatuh pada bulan November sampai Maret. Curah hujan rata rata pertahun adalah $125,2 \mathrm{~mm}$ sebagaimana dijelaskan di situs BKSDA NTB 2019.

Tabel 3. Faktor Abiotik Lingkungan

\begin{tabular}{ccc}
\hline No. & Faktor Abiotik & Kadar \\
\hline 1 & Suhu udara & $25-30^{\circ} \mathrm{C}$ \\
2 & Intensitas cahaya & $5 \mathrm{Cd}$ \\
3 & $\mathrm{pH}$ & 7 \\
4 & Curah hujan & $125,2 \mathrm{~mm}$ \\
\hline
\end{tabular}

Serangga merupakan hewan berdarah dingin (poikiloterm) sehingga pertumbuhannya lebih cepat di tempat beriklim tropis, namun jika mereka hidup di tempat beriklim dingin pertumbuhannya lambat. Serangga dapat hidup pada kisaran suhu $15-40^{\circ} \mathrm{C}$, keberlangsungan hidupnya paling baik pada suhu yaitu $25^{\circ} \mathrm{C}$. Dengan demikian, mengacu pada hasil penelitian ini, suhu di TWA Kerandangan termasuk mendukung pertumbuhan populasi serangga tanah. Fluktuasi suhu tanah lebih rendah dibandingkan suhu udara, dan suhu tanah bergantung pada suhu udara. Suhu tanah lapisan atas mengalami fluktuasi dalam sehari semalam dan tergantung musim, keadaan cuaca, keadaan tanah dan topografi daerah (Suin, 2012). Dengan demikian, fluktuasi suhu permukaan tanah termasuk tidak signifikan, sehingga diperkirakan tidak berpengaruh terhadap kehidupan serangga tanah walaupun jika penelitian di TWA tersebut dilakukan pada musim yang berbeda.

$\mathrm{pH}$ tanah di TWA Kerandangan termasuk netral ( $\mathrm{pH} 7)$. Tanah dengan $\mathrm{pH}$ netral akan mendukung percepatan fermentasi bahan organik sehingga lebih mudah diuraikan. Apabila kondisi tanah terlalu asam atau terlalu basa maka dapat berakibat pada keanekaragaman serangga yang rendah, karena kelangsungan hidupnya akan terganggu. Hanya serangga tipe asidofil yang bisa hidup pada kondisi tanah asam dan serangga tipe halofil yang bisa hidup di kondisi tanah basa.

Jenis flora yang mendominasi adalah Kelicung (Dyospiros malabrica). Vegetasinya tersebar mulai dari pintu masuk TWA hingga ke daerah tengah dan daerah paling ujung kawasan tersebut. Kelicung dapat tumbuh pada berbagai jenis tanah seperti tanah berkapur, tanah berpasir, tanah berbatu yang bersifat permeabel, dan tanah liat, tumbuh di tempat dengan ketinggian 50-400 mdpl dan masih dapat hidup pada ketinggian 700 mdpl dengan pertumbuhan yang kurang baik (Mayasari et al., 2012). Kelicung termasuk salah satu jenis kayu hitam atau lebih dikenal dengan kayu eboni merupakan jenis kayu yang bernilai ekonomi tinggi, mewah, dan indah yang dapat dipakai sebagai bahan mebel, ukiran, peralatan rumah tangga, perahu, dan patung (Suryanullah et $a l, 2016)$. Jenis flora yang ditemukan pada lokasi penelitian di TWA Kerandangan secara terperinci disajikan pada Tabel 4.

Tabel 4. Jenis-Jenis Flora yang Ditemukan

\begin{tabular}{cllll}
\hline No. & \multicolumn{1}{c}{ Famili } & \multicolumn{1}{c}{ Nama Ilmiah } & \multicolumn{1}{c}{ Nama Lokal } & Habitus \\
\hline 1 & Meliaceae & Aglaia sp. & Sentul & Pohon \\
2 & Moraceae & Arthocarpus elastica & Terep & Pohon \\
3 & Anacardiaceae & Dracontomellon mangiferum & Klokos udang & Pohon
\end{tabular}




\begin{tabular}{lllll}
4 & Ebenaceae & Dyospiros malabarica & Kelicung & Pohon \\
5 & Myrtaceae & Eugenia sp. & Jukut & Pohon \\
6 & Moraceae & Ficus Benjamin & Beringin & Pohon \\
7 & Moraceae & Ficus sp. & Goak & Pohon \\
\hline
\end{tabular}

Beranekaragamnya bentuk dan komposisi tanaman memberikan kesempatan lebih banyak jenis serangga dapat memanfaatkan tanaman. Dengan kata lain, apabila keanekaragaman spesies vegetasi meningkat maka jumlah spesies serangga tanah juga akan ikut bertambah. Pada daerah hutan khususnya hutan di kawasan TWA Kerandangan terdapat relatif banyak variasi jenis vegetasi, sehingga hal tersebut sebenarnya merupakan faktor pendukung dari kehadiran jumlah serangga yang lebih banyak. Namun, pengambilan data yang dilakukan saat memasuki musim penghujan dapat menyebabkan efektifitas perangkap jebak yang dipasang berkurang.

\section{Kesimpulan}

Berdasarkan temuan penelitian di Taman Wisata Alam Kerandangan maka dapat disimpulkan bahwa serangga yang teridentifikasi di Taman Wisata Alam Kerandangan terdiri dari 7 ordo, 11 famili dan 12 spesies. Ordo tersebut meliputi Coleoptera, Dermaptera, Homoptera, Hymnoptera, Isoptera, Orthoptera dan Spirobolida. Adapun famili yang didapat meliputi Alleculidae, Carabidae, Scarabaeidae, Anislabididae, Forficulidae, Cicadidae, Rhinotermitidae, Formicidae, Gryllidae, Tettigoniidae, dan Trigoniulidae. Indeks keanekaragaman (H') serangga di TWA Kerandangan Lombok Barat yaitu sebesar 1,768 dan termasuk kategori sedang. Indeks dominansi (D) serangga di TWA Kerandangan Lombok Barat yaitu sebesar 0,002, termasuk kategori rendah.

\section{Ucapan Terima Kasih}

Penelitian ini terlaksana dengan baik adalah berkat adanya bantuan dari berbagai pihak, untuk itu penulis mengucapkan terima kasih kepada rekan mahasiswa Pendidikan Biologi FKIP Unram angkatan tahun 2015 yang telah membantu dalam kegiatan pengambilan data, serta kepada pihak pengelola TWA Kerandangan yang telah memberikan izin untuk melakukan penelitian di tempat tersebut.

\section{Referensi}

Basna, M, Koneri, R. \& Papu, A. (2017). Distribusi dan Diversitas Serangga Tanah di Taman Hutan Raya Gunung Tumpa Sulawesi Utara. Jurnal MIPA Unsrat Online, 6 (1) 36-42.

https://doi.org/10.35799/jm.6.1.2017.1 6082

BKSDA. (2018). Taman Wisata Alam Kerandangan Lombok Barat. http://bksdantb.org/88/09/taman-wisataalam-kerandangan-batu-layar-kabupatenlombok-barat/

Borror, D. J., Triplehorn, C.A, \& Johnson, N.F. (1996). Pengenalan Pengajaran Serangga, Terjemahan oleh Soetiyono Partosoedjono. Yogyakarta: UGM Press.

Ilhamdi, M. L. (2012). Keanekaragaman Serangga Dalam Tanah di Pantai Endok Lombok Barat. Jurnal Pijar MIPA, 7(2), 55-59. https://doi.org/10.29303/jpm.v7i2.95

Ilhamdi, M. L. (2018). Pola Penyebaran Capung (Odonata) di Kawasan Taman Wisata Alam Suranadi Lombok Barat. Jurnal Biologi Tropis, 18(1). https://doi.org/10.29303/jbt.v18i1.508

Ilhamdi, M. L., Idrus, A. A., \& Santoso, D. (2019). Kekayaan Jenis Capung di Taman Wisata Alam (TWA) Suranadi Sebagai Bahan Penyusunan Buku Suplemen IPA. Prosiding Seminar Nasional SIMBIOSIS IV, hal. 8-14 Madiun, 15 Agustus 2019. http://prosiding.unipma.ac.id/index.php/si mbiosis/article/view/1323 
Haneda, N. F.., Kusmana, C., \& Kusuma, F. D. (2013). Keanekaragaman Serangga di Ekosistem Mangrove. Jurnal Silvikultur Tropika, 4(1), 42-46. https://core.ac.uk/download/pdf/29485457 $\underline{4 . p d f}$

Mayasari, A., Kinho, J., \& Suryawan, A. (2012). Asosiasi Eboni (Dyospiros spp.) Dengan Jenis-Jenis Pohon Dominan di Cagar Alam Tangkoko Sulawesi Utara. Info Balai Penelitian Kehutanan Manado, 2(1). 5572.

https://www.researchgate.net/publication/ 260337611_asosiasi_eboni_diospyros_sp p_dengan_jenisjenis_pohon_dominan_di_ cagar_alam_tangkoko_sulawesi_utara

Maulana, A. M., Iqbal, D., \& Sopyan, T. (2016). Keanekaragaman Jenis Serangga di Kawasan Hutan Lindung Karangkamulyan Kabupaten Ciamis. Jurnal Pendidikan Biologi (Bioed), 1(4). 69-72. https://doi.org/10.25157/jpb.v4i1.559

Patang, F. (2010). Keanekaragaman Takson Serangga Dalam Tanah Pada Areal Hutan Bekas Tambang Batubara PT. Mahakam Sumber Jaya Desa Separi Kutai Kartanegara, Kalimantan Timur. Jurnal Bioprospek, $\quad 7(1) . \quad 80-89$. https://scholar.google.com/scholar?cluster $=16641077607538547069 \& \mathrm{khl}=\mathrm{en} \& \mathrm{oi}=\mathrm{sc}$ holarr

Price, P. W. (1997). Insect Ecology Third Edition. New York: John Willey and Sons inc.

Rachmasari, O. D., Prihanta, W. \& Susetyarini, R. E. (2016). Keanekaragaman Serangga Permukaan Tanah di Arboretum Sumber Brantas Batu-Malang Sebagai Dasar Pembuatan Sumber Belajar Flipchart. Jurnal Pendidikan Biologi Indonesia, 2(2). https://doi.org/10.22219/jpbi.v2i2.3764

Soegianto, A. (1994). Ekologi Kuantitatif. Surabaya: Usaha Nasional.
Suana, I W., Amin, S., Ahyadi, H., Kalih, S., \& Tilat, L. A. T., Hadiprayitno, G. (2016). Birdwatching di Taman Wisata Alam Kerandangan. Yogyakarta: Penerbit KMedia.

Suhaeriyanto, D. (2008). Ekologi Serangga. Malang: Universitas Islam Negeri Maulana Malik Ibrahim Press.

Suin, M. N. (2012). Ekologi Hewan Tanah. Jakarta: Bumi Aksara.

Suryanullah, A., Subagio, S., \& Mirawati, B. (2016). Efektifitas Pupuk Kompos, Pupuk Kandang dan Urea Terhadap Pertumbuhan Bibit Klicung (Dyospiros malabarica Desr. Kostel). Jurnal Ilmiah IKIP Mataram, 3(1). 596-603. https://ejournal.undikma.ac.id/index.php/jiim/artic le/view/157 